\title{
Distribution of Metals in Tissues of the Common Carp (Cyprinus carpio L.)
}

\author{
O. ČELECHOVSKÁ ${ }^{1}$, Z. SVOBODOVÁ ${ }^{1,2}$, V. ŽLÁBEK ${ }^{2}$, B. MACHARÁČKOVÁ ${ }^{1}$ \\ ${ }^{1}$ Department of Biochemistry, Chemistry and Biophysics, Faculty of Veterinary Hygiene and Ecology, \\ University of Veterinary and Pharmaceutical Sciences, Brno, Czech Republic \\ ${ }^{2}$ University of South Bohemia, České Budějovice, \\ Research Institute of Fish Culture and Hydrobiology, Vodňany, Czech Republic \\ Received March 12, 2007 \\ Accepted July 9, 2007
}

\begin{abstract}
Čelechovská O., Z. Svobodová, V. Žlábek, B. Macharáčková: Distribution of Metals in Tissues of Common Carp (Cyprinus carpio L.). Acta Vet. Brno 2007, 76: S93-S100.

The aim of the present study was to investigate the distribution of selected metals (As, Cd, $\mathrm{Pb}, \mathrm{Hg}, \mathrm{Cr}, \mathrm{Cu}$ and $\mathrm{Zn}$ ) in tissues of the common carp (Cyprinus carpio L.) grown in ponds. A total of 125 market-ready carp (aged 3 - 4 years, weight $2312 \pm 583 \mathrm{~g}$ ) from 10 fishponds in the Czech Republic were analysed. The tissues analysed included muscle, liver, kidney, spleen, gills, ovaria and testes. Metal concentrations were determined by the AAS, mercury was determined using a cold-vapour AAS analyse (AMA 254). Results showed different affinities of metals to different tissues. The highest concentrations of $\mathrm{As}$ and $\mathrm{Hg}$ were in muscle tissue, $\mathrm{Cu}$ in the liver, and $\mathrm{Cd}$ and $\mathrm{Zn}$ in the kidneys, compared with levels in other tissues $(p<0.01)$. The lowest metal concentrations (particularly of $\mathrm{Cd}$ ) were found in the spleen, gills and gonads. Lead concentrations in the individual tissues were low and practically identical. Chromium concentrations were also balanced with sporadic significant differences $(p<0.05)$. Significantly higher concentrations of $\mathrm{Cu}, \mathrm{Cr}(p<0.05)$ and $\mathrm{Zn}(p<0.01)$ were found in the ovaria compared with the testes. The study showed that meat and gonads of pond carp in the Czech Republic are safe from the point of view of contamination with the metals investigated.
\end{abstract}

Muscle, parenchymatous tissues, gills, gonads, arsenic, cadmium, lead, mercury, chromium, copper, zinc

An increase in metal concentrations in the environment is due primarily to erosion and anthropogenic activities, and because metals are very persistent pollutants, they get accumulated in the soil, water sediments and, last but not least, in the food chain (Radike et al. 2002; Reinecke et al. 2003; Cornelis et al. 2005; Swaileh and Sansur 2006). Recurrent cycles are the raison d'être for conducting contamination monitoring in both the environment and the links of food chains in order to guarantee food quality and safety (Svobodová et al. 2002ab, 2004; Andreji et al. 2006a). One of the most closely monitored area is the aquatic ecosystem, and fish as the final link of the food chain in particular (Yilmaz 2006; Havelková et al. 2007). Great attention is paid to hazardous elements such as mercury, lead, cadmium and arsenic (Alam et al. 2002; Maffuci et al. 2005). A large majority of metals have a great affinity to bind with amino acids and SH groups of proteins, and therefore act as enzyme inhibitors. An important negative characteristic of metals is their ability to accumulate in organs, especially in the liver, spleen, kidneys and gonads (Spurný et al. 2002; Yilmaz 2006; Andreji et al. 2006b). To better understand not only physiological effects but also toxicological and hygienic effects of metals, it is necessary to know the distribution patterns of individual metals in the organism. The distribution of metals in tissues of different species of fish has been described by, e.g., Staniskiene et al. (2006) (perch, roach, silver bream, chub, smelt, tench and pike) and Spurný et al. 2002 (chub).

The aim of the present study was to investigate the distribution of selected metals in tissues of the common carp (Cyprinus carpio L.) grown in ponds. Like in many other European

Address for correspondence:

Doc. Ing. Olga Čelechovská, Ph.D.

Department of Biochemistry, Chemistry and Biophysics

Faculty of Veterinary Hygiene and Ecology

University of Veterinary and Pharmaceutical Sciences

Palackého 1-3, 61242 Brno, Czech Republic

Phone +420541562606

E-mail: celechovskao@vfu.cz

http://www.vfu.cz/acta-vet/actavet.htm 
countries, carp is the principal commercially exploited fish in the Czech Republic. Carp production makes up about $87-90 \%$ of the total fish production in the Czech Republic (Vácha 1998).

\section{Materials and Methods}

Between 2000 and 2006, we examined 125 market-ready carp from 10 uncontaminated fishponds in the Czech Republic, i.e. Bezdrev (17 carp), Velký Bědný (7 carp), Dřemliny (17 carp), Horusický (17 carp), Nezmar (7 carp), Regent (17 carp), Rožmberk (16 carp), Spolský (10 carp), Tovaryš (17 carp) and Vrkoč starý (10 carp) (Fig. 1).

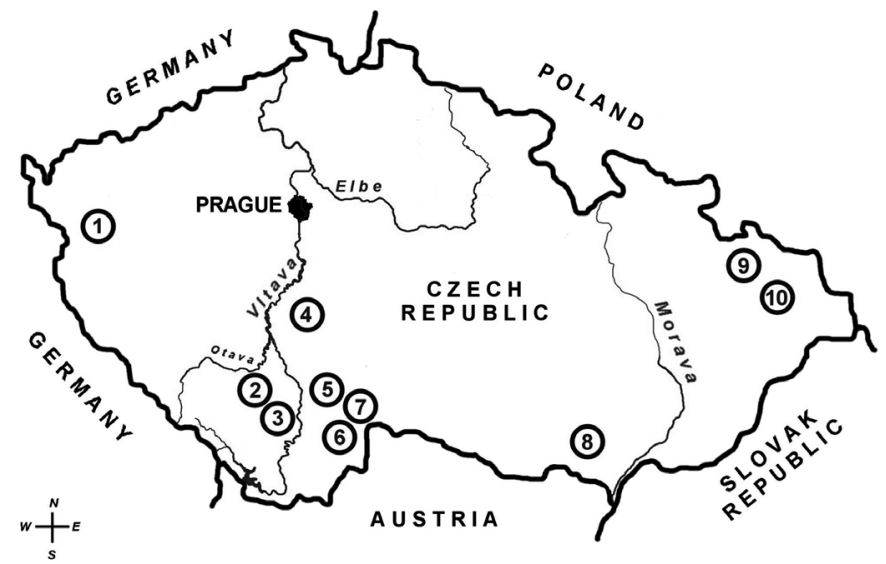

Fig. 1. Location of the ponds (1 - Regent 52 ha, 2 - Dřemliny 57 ha, 3 - Bezdrev 450 ha, 4 -Tovaryš 16 ha, 5 - Horusický 438 ha, 6 - Spolský 124 ha, 7 - Rožmberk 647 ha, 8 - Vrkoč 160 ha, 9 - Nezmar 65 ha, 10 - Bědný 23 ha)

The tissues analysed included muscle, liver, caudal kidney, spleen, gills, ovaria and testes. Samples were tested for the concentration of arsenic (63 samples), cadmium (94), chromium (98), lead (96), copper (100), mercury (125) and zinc (103). The fish were obtained during autumn harvesting. The carp were 3 - 4 years old and weighed $2312 \pm 583 \mathrm{~g}$.

Samples of individual tissues were collected immediately after the fish were sacrificed. The samples were kept at $-18{ }^{\circ} \mathrm{C}$ until the analyses were carried out. Prior to the elements determination by atomic absorption spectrometry (AAS), samples were mineralized using nitrogen acid and hydrogen peroxide in laboratory autoclaves with microwave heating (Uniclever, Plasmatronica Poland, ETHOS SEL, Milestone Italy). For arsenic determination, samples were ashed in a muffle furnace with added $\mathrm{Mg}\left(\mathrm{NO}_{3}\right)_{2}$. Metals were determined by electrothermic atomization $(\mathrm{Cd}, \mathrm{Pb}, \mathrm{Cr}, \mathrm{Pb})$, hydride technique (As) and flame atomization $(\mathrm{Zn}, \mathrm{Cu})$. All AAS measurements were made using a Z-5000 spectrometer (Perkin Elmer, USA). Mercury concentrations were determined using a single-purpose cold-vapour AMA 254 mercury analyzer (Altec s.r.o., CZ) with $0.01 \mathrm{ng} \mathrm{Hg}$ detection limit. The following detection limits $(3 \sigma)$ were used: As $1 \mu \mathrm{g} \cdot \mathrm{kg}^{-1}, \mathrm{Cd} 1.25 \mu \mathrm{g} \cdot \mathrm{kg}^{-1}, \mathrm{~Pb} 10 \mu \mathrm{g} \cdot \mathrm{kg}^{-1}, \mathrm{Cu}$ $10 \mu \mathrm{g} \cdot \mathrm{kg}^{-1}, \mathrm{Cr} 12 \mu \mathrm{g} \cdot \mathrm{kg}^{-1}, \mathrm{Zn} 28 \mu \mathrm{g} \cdot \mathrm{kg}^{-1}$. Samples of reference materials BCR No 278 (muscle tissue), BCR No 185 (bovine liver), BCR No 186 (pig kidney) and IAEA MA-B-3/TM (fish homogenate) were used to check the validity and accurancy of the method (ranged with $95 \%$ confidence interval).

The data obtained were statistically evaluated using Unistat 5.1 statistical software. To assess the agreement $(p<0.05)$ or differences between the individual tissue groups, nonparametric median multiple comparisons by Tukey-HSD tests were used.

\section{Results and Discussion}

Distribution of individual metals in carp tissues is shown in Figs. 2 - 7. The following statistical values related to native tissues are given in the diagrams: Bottom (top) line of the box $=$ Lower (Upper) Quartile, Middle line of the box = median, Lower (Upper) Whisker $=$ Lower (Upper) adjacent value, Notch $=$ standard error. 
It follows from box diagrams that the data in individual tissue groups do not correspond to normal distribution. Groups with different alphabetic superscripts differ significantly at $p<0.05$ or $p<0.01$.

No statistically significant differences in metal concentrations in individual tissue between different fishponds or sexes were demonstrated.

\section{Arsenic}

Fig. 2 shows arsenic distribution in individual tissues. Three homogenous groups of concentrations $(a, b, c)$ were ascertained that are significantly different at $95 \%$. The highest arsenic concentrations were found in muscle tissue $>$ kidneys $>$ liver and ovaria $>$ testes. There was a tenfold difference in arsenic concentrations between tissues with the highest and the lowest median concentrations. Arsenic concentrations in muscle tissue were very low (median $0.086 \mathrm{mg} \cdot \mathrm{kg}^{-1}$, mean $0.092 \mathrm{mg} \cdot \mathrm{kg}^{-1}$ ).

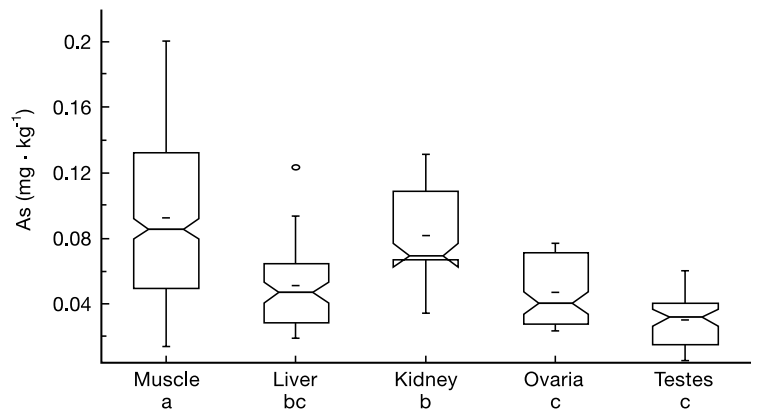

Fig. 2. Distribution of arsenic in tissues of carp. Groups with different alphabetic superscripts differ significantly.

\section{Cadmium}

Cadmium distribution in carp tissues is shown in Fig. 3. Three statistically significant homogeneous groups $(a, b, c)$ of cadmium concentrations were identifiable in the set of tissues. Due to a very long elimination half-life, cadmium gets accumulated in tissues (Cornelis et al. 2005). The pattern of cadmium distribution was kidneys $>$ liver $>$ muscle tissue, gills $>$ spleen, ovaria and testes. Cadmium concentrations in the kidneys were 100 times higher than those in muscle tissue, gills or gonads. Cadmium concentrations in carp muscle tissue were low (median 0.0016 ; mean $0.0026 \mathrm{mg} \cdot \mathrm{kg}^{-1}$ ). The same results were reported by Paláčková et al. (1994), Drastichová et al. (2004) and Reynders et al. (2006) from their experimental cadmium contamination laboratory studies.

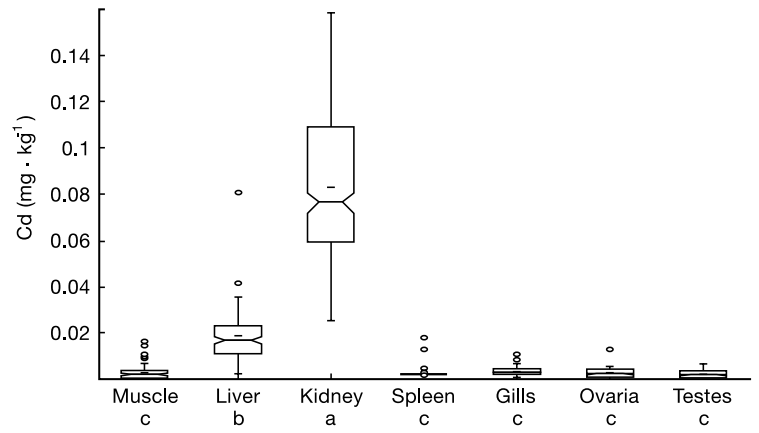

Fig. 3. Distribution of cadmium in tissues of carp. Groups with different alphabetic superscripts differ significantly. 


\section{Lead}

Lead concentrations in carp tissues were low, and no statistical significant differences in concentrations between different tissues were found. Lead concentrations in muscle tissue were very low (median 0.026; mean concentration $0.037 \mathrm{mg} \cdot \mathrm{kg}^{-1}$ ).

\section{Mercury}

Mercury is a highly toxic and the most closely monitored contaminant in fish. Four statistically significant homogeneous groups (a, b, c, d) of mercury concentrations were found at the $p<0.05$ level of significance. Its tissue distribution is given in Fig. 4 . The highest concentrations were found in muscle tissue $>$ kidneys $>$ liver $>$ spleen, ovaria and testes $>$ gills. Because of its cycle in nature, mercury remains a topical issue. From the hygienic point of view, mercury concentrations found in carp muscle tissue were low (median 0.026; mean concentration $0.031 \mathrm{mg} \cdot \mathrm{kg}^{-1}$ ).

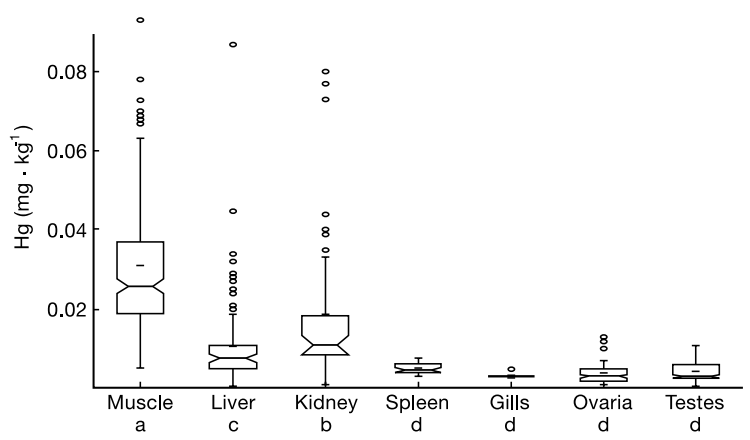

Fig. 4. Distribution of mercury in tissues of carp. Groups with different alphabetic superscripts differ significantly.

\section{Chromium}

Fig. 5 shows the chromium distribution in carp tissues. Four homogeneous groups $(a, b$, $\mathrm{c}, \mathrm{d})$ were found at the $p<0.05$ level of significance. The greatest concentration was found in the gills. $\mathrm{Cr}$ concentrations in individual tissues were balanced with sporadic significant differences $(p<0.05)$. Chromium concentration in muscle tissue (median 0.031; mean concentration $\left.0.040 \mathrm{mg} \cdot \mathrm{kg}^{-1}\right)$ was low.

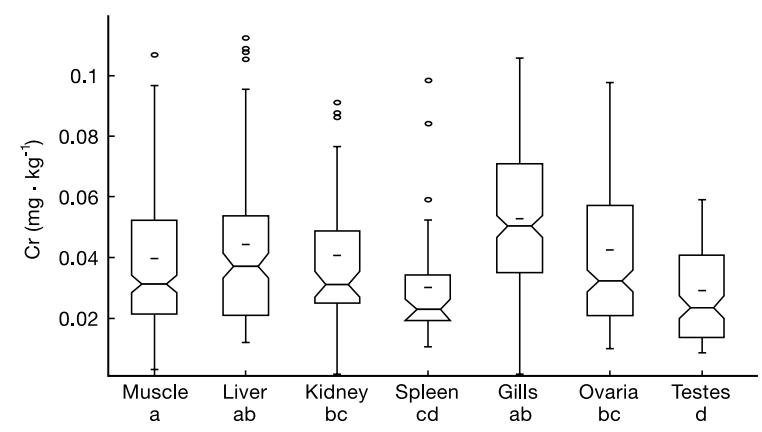

Fig. 5. Distribution of chromium in tissues of carp. Groups with different alphabetic superscripts differ significantly. 


\section{Copper}

Copper is a constituent of a number of enzymes, and its highest concentrations in the liver were almost 20 times higher than the lowest concentrations in muscle tissue $(p<$ 0.01) (Fig. 6). Three homogeneous groups at the $p<0.05$ level of significance were found. The other tissues according to $\mathrm{Cu}$ concentrations were in the order: kidneys, ovaria, gills, spleen and testes. Copper concentrations in muscle tissue (median 0.217, mean 0.237 $\mathrm{mg} \cdot \mathrm{kg}^{-1}$ ) were very low.

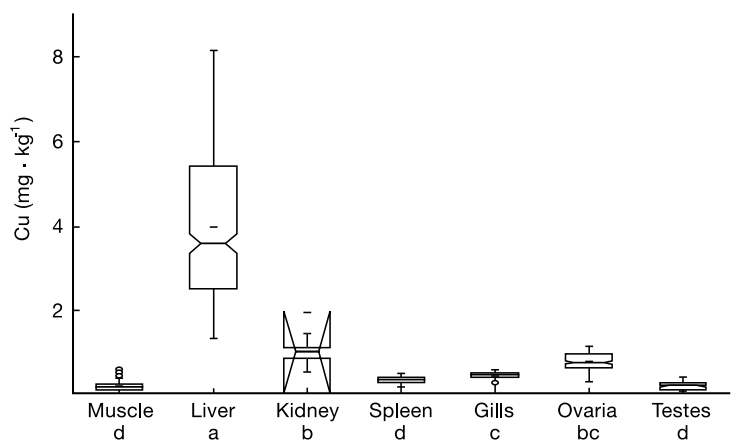

Fig. 6. Distribution of copper in tissues of carp. Groups with different alphabetic superscripts differ significantly.

Zinc

Zinc tissue distribution is given in Fig. 7. Four homogeneous groups (a, b, c, d) were found at the $p<0.05$ level of significance. The highest zinc concentrations were found in the kidneys $>$ gills $>$ ovaria $>$ liver $>$ spleen $>$ testes $>$ muscle tissue. Zinc concentrations in the kidneys were 40 times higher than those in muscle tissue. Zinc concentrations in muscle tissue (median 4.9, mean $5.3 \mathrm{mg} \cdot \mathrm{kg}^{-1}$ ) were very low.

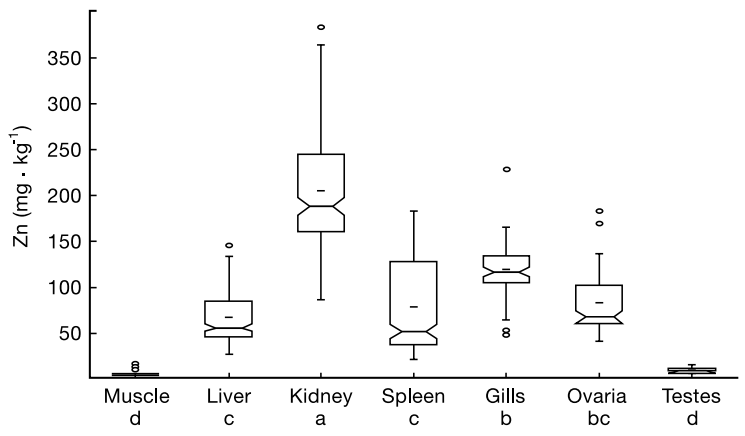

Fig. 7. Distribution of zinc in tissues of carp. Groups with different alphabetic superscripts differ significantly.

The investigations demonstrated that metals have different affinities to different tissues.

The highest concentrations of $\mathrm{As}$ and $\mathrm{Hg}$ were in muscle tissue, of $\mathrm{Cu}$ in the liver, and of $\mathrm{Cd}$ and $\mathrm{Zn}$ in the kidneys, compared with findings in other tissues $(p<0.01)$. The lowest metal concentrations (particularly of $\mathrm{Cd}, \mathrm{Cu}$ and $\mathrm{Hg}$ ) were found in the spleen, gills and gonads. 
High concentrations of metals in the liver and kidneys are related to detoxification and excretion processes that take place in these organs. Furthermore, metals are bound here to specific polypeptides, i.e. metallothioneins (Jezierska and Witeska 2001). Concentrations of metals in gills reflect concentrations of metals in water where the fish live. Metal concentrations in fishpond water are low, and, moreover, a large part of metals is bound to undissolved substances (Pitter 1999). This reduces metal bioavailability for fish. However, gills of the fish examined were found to contain significantly higher concentrations of copper and zinc than muscle tissue $(p<0.05)$. The same conclusion was reached by Sidoumou et al. (2005) in their analysis of sea fish. They propose that higher concentrations of the above metals in the gills compared with muscle tissue are the result of high volumes of water being filtered through the gills. Higher mercury concentrations in muscle tissue $(p<0.05)$ compared with other tissues is an indication that the fish analysed were captured in fishponds not contaminated with mercury. Data from earlier studies (Svobodová et al. 1995; Foster et al. 2000; Linde et al. 2004; Havelková et al. 2007) indicate that in fish from heavily contaminated localities $\mathrm{Hg}$ was deposited preferentially in the liver, while in slightly contaminated areas, it was deposited preferentially in muscle.

Significantly higher zinc $(p<0.01)$ and copper $(p<0.05)$ concentrations were found in carp ovaria than in the testes. Our results corroborate the data published by Marquez et al. (1998) who found higher copper and zinc concentrations in the ovaria than in testes of Notothenia coriiceps. Seymore et al. (1996) also stated higher content of zinc in ovaria than in testes of Barbus marequensis. Fish ovaries are a complicated system with a rich source of energy indispensable for the entire embryonic period of development. For that reason, ovaries have higher concentrations of essential metals that are part of basal metabolism enzymes.

Concentrations of toxic elements in muscle of carp from 10 fishponds from the Czech Republic were very low in comparison with those found in carp from fishponds in the Slovak Republic (Horné Obdokovce and Budmerice fishponds - Andreji 2006a). From the point of view of risk metals investigated in this study, consumption of meat of fishpond carp is safe.

\section{Distribuce kovů ve tkáních kapra obecného (Cyprius carpio L.)}

Cílem předkládané práce bylo zjistit rozložení vybraných kovů ( $\mathrm{As}, \mathrm{Cd}, \mathrm{Pb}, \mathrm{Hg}, \mathrm{Cr}$, $\mathrm{Cu}$ a Zn) ve tkáních rybničních kaprů obecných (Cyprinus carpio L.) Analyzováno bylo 125 kusů tržních kaprů (věk 3 - 4 roky, hmotnost 2312 土 583 g) z 10 rybníků České republiky. Analyzovány byly: svalovina, játra, ledviny, slezina, žábry, ovaria a testes. Ke stanovení kovů byla použita metoda AAS, rtut' byla stanovena na jednoúčelovém analyzátoru rtuti AMA 254. Výsledky ukázaly, že různé kovy mají rozdílnou afinitu $\mathrm{k}$ různým tkáním. Nejvyšší obsah $\mathrm{As}$ a $\mathrm{Hg}$ byl nalezen ve svalovině, $\mathrm{Cu}$ v játrech a $\mathrm{Cd}$ a Zn v ledvinách ve srovnání s nálezem u ostatních tkání $(p<0,01)$. Nejnižší hodnoty kovů, zejména $\mathrm{Cd}, \mathrm{Cu}$ a $\mathrm{Hg}$, byly zjištěny ve slezině, žábrách a v gonádách. Obsah $\mathrm{Pb}$ byl v jednotlivých tkáních nízký a prakticky shodný. Rovněž obsah Cr byl vyrovnaný $\mathrm{s}$ ojedinělými signifikatními diferencemi $(p<0,05)$. Signifikantně vyšší hodnoty $\mathrm{Cu}$ a $\mathrm{Cr}(p<0,05)$ a $\mathrm{Zn}(p<0,01)$ byly naměřeny v ovariích ve srovnání s testes. Studie ukázala, že konzum masa a gonád kaprů je v České republice bezpečný z hlediska kontaminace sledovanými kovy.

\section{Acnowledgement}

This study was supported by the Ministry of Education, Youth and Physical Training of the Czech Republic, Project MSM No 6215712402 and MSM No 6007665809. 


\section{References}

ALAM MGM, TANAKA A, ALLINSON G, LAURENSON LJB, STAGNITTI F, SNOW ET 2002: A comparison of trace element concentrations in cultured and wild carp (Cyprinus carpio) of Lake Kasumigaura, Japan. Ecotox Environ Safe 53: 348-354

ANDREJI J, STRANAI I, KACANIOVÁ M, MASSANYI P, VALENT M 2006a: Heavy metals content and microbiological quality of carp (Cyprinus carpio L.) muscle from two southwestern Slovak fish farms. J Environ Sci Health Part A-Toxic/Hazard Subst Environ Eng 41: 1071-1088

ANDREJI J, STRANAI I, MASSANYI P, VALENT M 2006b: Accumulation of some metals in muscles of five species from lower Nitra River. J Environ Sci Health Part A-Toxic/Hazard Subst Environ Eng 41: 2607-2622

CORNELIS R, CARUSO J, CREWS H, HEUMANN K 2005: Handbook of Elemental Speciacion II. Species in the environment, food, medicine and occupational health. Wiley, Chichester, England, 768 p.

DRASTICHOVÁ J, SVOBODOVÁ Z, LUSKOVÁ V, ČELECHOVSKÁ O, KALÁB P 2004: The effect of cadmium on blood plasma biochemistry in carp (Cyprinus carpio L.). Bull Environ Contam Toxicol 72: 733740

FOSTER EP, DRAKE DL, DIDOMENICO G 2000: Seasonal changes and tissue distribution of mercury in largemouth bass (Micropterus salmoides) from Dorena Reservoir, Oregon. Arch Environ Contam Toxicol 38: 78-82

HAVELKOVÁ M, SVOBODOVÁ Z, DUŠEK L, NÉMETHOVÁ D, JARKOVSKÝ J 2007: Comparison of tissue distribution of mercury in fish from lightly and heavily contaminated localities. Ecotox Environ Safe: In press.

JEZIERSKA B, WITESKA M 2001: Metal toxicity to fish. Wydawnicko akademii Podlaskiej, Siedlce. 318 pp.

LINDE AR, SANCHEZ-GALAN S, GARCIA-VAZQUEZ E 2004: Heavy metal contamination of European eel (Anquilla Anquilla) and brown trout ( Salmo trutta) caught in wild ecosystems in Spain. J Food Protect 67: 2332-2336

MAFFUCCI F, CAURANT F, BUSTAMANTE P, BENTIVEGNA F 2005: Trace element (Cd, Cu, Hg, Se, Zn) accumulation and tissue distribution in loggerhead tertles (Caretta caretta) from the Western Mediterranean Sea (Southern Italy). Chemosphere 58: 535-542

MARQUEZ M, VODOPIVEZ C, CASAUX R, CURTOSI A 1998: Metal (Fe, Zn, Mn and Cu) levels in the Antarctic fish Notothenia coriiceps. Polar Biol 20: 404-408

PALÁČKOVÁ J, PRAVDA D, FAŠAIC K, ČELECHOVSKÁ O 1994: Sublethal effects of cadmium on carp (Cyprinus carpio) fingerlings. In MULLER R, LLOYD R (Eds): Sublethal and chronic effects of pollutants on freshwater fish. Fisch News Books, Blackwell Sci, pp. 53-61

PITTER P 1999: Hydrochemie. Ed. Vydavatelství VŠCHT Praha. 568 p.

RADIKE M, WARSHAWSKY D, CARUSO J, GOTH-GOLDSTEIN R, REILMAN R, COLLINS T, YAEGER M, WANG JS, VELA N, OLSEN L, SCHNEIDER J 2002: Distribution and accumulation of a mixture of arsenic, cadmium, nickel and vanadium in mouse small intestine, kidneys, pancreas, and femur following oral administration in water or feed. J Toxicol Environ Health 65: 2029-2052

REINECKE AJ, SNYMAN RG, NEL JAJ 2003: Uptake and distribution of lead $(\mathrm{Pb})$ and cadmium $(\mathrm{Cd})$ in the freshwater crab, Potamonautes perlatus (Crustacea) in the Eerste river, South Africa. Water Air Soil Pollut 145: $395-408$

REYNDERS H, VAN CAMPENHOUT K, BERVOETS L, DE COEN WM, BLUST R 2006: Dynamics of cadmium accumulation and effects in common carp (Cyprinus carpio) during simultaneous exposure to water and food (Tubifex tubifex). Environ Toxicol Chem 25: 1558-1567

SEYMORE T, DU-PREEZ HH, VAN VUREN JHJ 1996: Concentration of zinc in Bambus marequensis from the lower Olifants River, Mpumalanga, South Africa. Hydrobiologia 332: 141-150

SIDOUMOU Z, GNASSIA-BARELLI M, SIAU Y, MORTON V, ROMÉO M 2005: Distribution and concentration of trace metals in tissues of different fish species from Atlantic coast of Western Africa. Bull Environ Contam Toxicol 74: 998-995

SPURNÝ P, MAREŠ J, HEDBAVNÝ J, SUKOP I 2002: Heavy metal distribution in the ecosystems of the upper course of the Jihlava River. Czech J Anim Sci 47: 160-167

STANISKIENE B, MATOSEVICIUS P, BUDRECKIENE R, SKIBNIEWSKA KA 2006: Distribution of heavy metals in tissues of freshwater fish in Lithuania. Pol J Environ Stud 15: 585-501

SVOBODOVÁ Z, PIAČKA V, VYKUSOVÁ B, MÁCHOVÁ J, HEJTMÁNEK M, HRBKOVÁ M, BASTL J 1995: Residues of pollutants in siluriformes from various localities of Czech Republic. Acta Vet Brno 64: 195-208

SVOBODOVÁ Z, ČELECHOVSKÁ O, MÁCHOVÁ J, RANDÁK T 2002a: Content of arsenic in market-ready rainbow trout (Oncorhynchus mykiss). Acta Vet Brno 71: 361-367

SVOBODOVÁ Z, ŽLÄBEK V, ČELECHOVSKÁ O, RANDÁK T, MÁCHOVÁ J, KOLÁŘOVÁ J, JANOUŠKOVÁ D 2002b: Content of metals in tissues of marketable common carp and in bottom sediments of selected ponds of South and West Bohemia. Czech J Anim Sci 47: 339-350

SVOBODOVÁ Z, ČELECHOVSKÁ O, KOLÁŔROVÁ J, RANDÁK T, ŽLÁBEK V. 2004: Assessment of metal contamination in the upper reaches of the Tichá Orlice River. Czech J Anim Sci 49: 458-464

SWAILEH KM, SANSUR R 2006: Monitoring urban heavy metal pollution using the house sparrow (Passer domesticus). J Environ Monit 8: 209-213 
VÁCHAF 1998: Information on Czech Republic fisheries. In: HICKLEY P, TOMPKINS H(Eds.): RECRETIONAL FISHERIES. Social, economic and management aspects, Fish News Book, Blackwell Sci, pp. 48-61

YILMAZ F 2006: Bioaccumulation of heavy metals in water, sediment, aquatic plants and tissues of Cyprinus carpio from Kizilirmak, Turkey. Fresen Environ Bull 15: 360-369 